\title{
Successional Transitions and Management of a Phosphorus-Limited Shrubland Ecosystem
}

\author{
Zalmen Henkin, ${ }^{1}$ No'am G. Seligman, ${ }^{2}$ and Imanuel Noy-Meir ${ }^{3}$
}

Authors are ${ }^{1}$ Research Scientist, Beef Cattle Section, Newe-Ya'ar Research Center, Department of Natural Resources, Agricultural Research Organization, PO Box 1021, Ramat Yishay 30095, Israel; ${ }^{2}$ Research Scientist, MIGAL-Galilee Technological Center, PO Box 831, Kiryat Shmona 11016, Israel; and ${ }^{3}$ Research Scientist, Institute of Plant Sciences, Faculty of Agricultural, Food and Environmental Quality Sciences, The Hebrew University of Jerusalem, Rehovot 76100, Israel.

\begin{abstract}
The decline of traditional pastoral systems has highlighted the problem of managing shrub encroachment on successional shrublands in the Mediterranean region, especially in marginal habitats. A long-term study of the response of ecosystem dynamics to phosphate amelioration and shrub control was initiated in 1988 on an area of phosphorus deficient terra rossa, dominated by dwarf shrubs that had been burnt in the summer of that year. The treatments were imposed in a replicated factorial design once at the beginning of the study. The area was previously grazed yearlong by goats, but during the experiment beef cattle grazed the area during the summer of each year. Without herbicide control, shrub cover reached its preburn level within 5 years, but with shrub control after 17 years, it had not yet reached the preburn level. The average shrub cover over the whole experimental period was $41.9 \%-49.1 \%$ without herbicide and $13.5 \%-24.4 \%$ with $(P<0.0001$, SE of the difference $=3.99$ ). The effect of phosphate application on shrub cover was not significant, but cover of herbaceous vegetation increased $(P<0.0016, \mathrm{SE}$ of difference $=5.03)$. A "state and transition" scheme was constructed that defines the interventions necessary to buffer any one of the states against the pressures of successional processes. Vegetation states were defined by the dominance of either herbaceous vegetation or one of two spiny shrub species, Prickly burnet (Sarcopoterium spinosum, Rosaceae) and Calicotome villosa (Fabaceae). The timing and scale of the interventions depend largely on landscape management objectives and on available economic and logistic resources. We conclude that appropriate management of grazing, periodic control of the shrub component, and occasional soil nutrient amelioration can lead to the development of attractive open woodland with a productive herbaceous understory that provides a wider range of ecological services than a landscape dominated by the undisturbed successional shrub thickets.
\end{abstract}

\section{Resumen}

La disminución de los sistemas pastoriles tradicionales ha resaltado el problema de manejar la invasión de arbustos en las comunidades arbustivas en sucesión de la región Mediterránea, especialmente en los hábitats marginales. En 1988 se inicio un estudio a largo plazo sobre la respuesta de la dinámica del ecosistema a la mejora con fósforo y el control de arbustos en un área "terra rossa" deficiente de fósforo y dominada por arbustos enanos, que habían sido quemados en el verano de ese año. Los tratamientos se aplicaron una vez, al inicio del experimento, bajo un diseño un diseño factorial repetido. El área fue previamente apacentada en forma continua por cabras, pero durante el estudio ganado bovino para carne la apacentó en el verano de cada año. Sin control con herbicida, la cobertura de arbustos alcanzó su nivel previo a la quema en cinco años y con control a los 17 años aun no había alcanzado este nivel. El promedio de cobertura de arbustos en todo el periodo experimental fue $41.9 \%$ $49.1 \%$ sin control con herbicidas y $13.5 \%-24.4 \%$ con control $(P<0.0001$, EE de la diferencia $=3.99)$. El efecto de la aplicación de fósforo sobre la cobertura de arbustos no fue significativa, pero la cobertura de vegetación herbácea se incrementó $(P<0.0016$, EE de la diferencia $=5.03)$. Se construyó un esquema de "estado y transición," que define las intervenciones necesarias para amortiguar cualquiera de los estados contra las presiones de los procesos sucesionales. Los estados de vegetación se definieron por la dominancia de la vegetación herbácea o por una de dos especies arbustivas espinosas, "Prickly burnet" (Sarcopoterium spinosum, Rosaceae), y Calicotome villosa (Fabaceae). La época y escala de las intervenciones depende grandemente de los objetivos de manejo del paisaje y de los recursos económicos y logísticos disponibles. Concluimos que el manejo adecuado del apacentamiento, el control periódico del componente arbustivo y el mejoramiento ocasional de los nutrientes del suelo pueden conducir al desarrollo bosque abierto, con un estrato herbáceo productivo y un amplio rango de servicios ecológicos, más atractivo que un paisaje dominado por una comunidad arbustiva cerrada sin disturbio.

Key Words: Calicotome villosa, fire, grazing, herbicide, Mediterranean, Sarcopoterium spinosum

Research was funded by a contribution from the Agricultural Research Organization, Bet Dagan, Israel, 117/2007.

Botanical names according to Feinbrun-Dothan and Danin (1991).

Correspondence: Zalmen Henkin, Beef Cattle Section, Newe-Ya'ar Research Center, Dept of Natural Resources, Agricultural Research Organization, PO Box 1021, Ramat Yishay 30095, Israel. Email: henkinz@volcani.agri.gov.il

Manuscript received 25 November 2006; manuscript accepted 17 May 2007.

\section{INTRODUCTION}

Over the past half century, the main objectives of land use in the more marginal lands in the northern countries of the Mediterranean basin have shifted from subsistence agriculture and animal husbandry to improvement of environmental and 
recreational values, conservation, and real estate development (Rundel et al. 1998). Consequently, the Mediterranean vegetation and landscape have undergone far-reaching changes. Following the removal of utilization pressure, the cover and biomass of the shrub and woody vegetation increased (Perevolotsky and Seligman 1998). In many cases, the densely wooded landscape has created an attractive environmental setting that also can become a serious fire hazard (Naveh 1974, 1975). However, when the landscape becomes dominated by spiny dwarf shrub thickets, its biodiversity, forage, and amenity values are low. Objectives of land management have changed from relatively well-defined production or subsistence aims to less well-defined environmental and ecological goals (Pretty 2002). In many parts of the eastern Mediterranean where spiny shrubs dominate, it is desirable to promote a vegetation mosaic that would be more heterogeneous at multiple scales with higher biodiversity, recreational, and forage values. These changes present a challenge to resource managers who need a deeper ecological understanding of the effects of management interventions and their relationship to management goals. The present study focuses on the dynamics of the shrub and herbaceous cover components of the ecosystem.

Zohary (1973) and others have described the sclerophyllic woody vegetation types of the Mediterranean countries. The vegetation occurs in diverse stages of development or degradation (Naveh and Dan 1973; Rivas Martinez 1987). Some of the vegetation types change slowly and persist for long periods, especially when landscape management (or nonmanagement) is constant. Such stable (quasi-stable?) secondary successional stages include shrublands like the ubiquitous prickly burnet Sarcopoterium spinosum (L.) Spach (Rosaceae) batha (sensu Zohary 1973), which dominates phosphorus-poor habitats in the eastern Mediterranean region (Litav and Orshan 1971; Reisman-Berman 2004). The leguminous spiny gorse-like Calicotome villosa (Poiret) Link (Fabaceae) also dominates large areas on phosphorus-poor habitats and often occurs together with S. spinosum. Other vegetation types, such as sparse herbaceous swards on abandoned terraces, tend to be more ephemeral and are often invaded by shrubby species that can dominate the vegetation within a relatively short time of 510 years (Henkin et al. 1999).

Protocols for management depend on the management objectives, and these can be realistic only if the rates of response to management intervention can be predicted with a fair degree of confidence. The factors that determine the rates of change are complex and include interactions and feedback processes that may promote either change or stability. The effects of some factors that are relevant to Mediterranean vegetation have been identified:

- On phosphorus-poor sites, dwarf shrubs often dominate (Rabinovich-Vin and Orshan 1974). S. spinosum dwarf shrub vegetation dominates large dolomitic areas that are characterized by phosphorus-deficient terra-rossa soils on which herbaceous vegetation is typically very sparse. After phosphate amelioration, nitrogen deficiency may become important, although the vegetation can become dominated by N-fixing annual Fabaceae species (Ofer and Seligman 1969) that add to the soil fertility of the site.
- It has been shown that survival of S. spinosum seedlings is highly sensitive to soil moisture stress during the first summer, and $S$. spinosum is often absent where vigorous herbaceous growth has exhausted the available soil moisture by the beginning of the summer (Henkin et al. 1998a). Cracking soils aggravate the summer moisture stress, and $S$. spinosum is virtually absent from such soils.

- Where S. spinosum has become established, especially on karstic habitats or on chalky substrates that have available moisture well below the rooting depth of the (mainly annual) herbaceous vegetation, vegetative propagation of the dwarf shrub is common (Seligman and Henkin 2000; Reisman-Berman 2004). Recovery after fire is predominantly from resprouting buds that have survived the fire, although seedling recruitment does occur, especially when the herbaceous vegetation is sparse.

- Goats graze both S. spinosum and C. villosa. Intensive goat grazing reduces the cover of both species, but C. villosa can be reduced almost to extinction. Cattle graze both $S$. spinosum and C. villosa sporadically but have virtually no effect on their cover (Henkin 2000).

- C. villosa grows to a height of up to $2 \mathrm{~m}$, whereas $S$. spinosum seldom grows taller than $50 \mathrm{~cm}$. Consequently, where both occur on an undisturbed site, C. villosa eventually dominates (Henkin et al. 1999).

- When exogenous P is added to P-deficient soils, the herbaceous vegetation responds strongly for many years. Available (bicarbonate-extractable) $\mathrm{P}$ in the soil declines rapidly during the years after application but remains above the original levels for 5-6 years after application (Henkin et al. 1998c).

The objective of the present study was to derive the rates at which vegetation cover changes from one type to another both under conditions of undisturbed successional processes and where the successional process is interrupted by management intervention or by wildfire. These data can then serve to construct a quantitative model of the vegetation dynamics of the shrub-herbaceous community.

The classical Clementsian model of succession was found to be inadequate to account for changes that are not unidirectional (Allen-Diaz and Bartolome 1998). The flexibility of the more empirical "state and transition" (S\&T) model (Westoby et al. 1989; Bestelmeyer et al. 2003; Stringham et al. 2003) is able to accommodate the observed changes more directly. It can also provide a suitable framework for describing the dynamics of different disturbances in Mediterranean shrublands. The rates derived from our experimental data can then be used to quantify an S\&T model with applicability to landscape management. The ecological understanding derived from the study can be applied in the region and in other Mediterranean regions where similar shrubby ecosystems dominate on P-deficient soils and where annual legume species are common components of the vegetation. Most of our data were derived from a relatively long-term (17-year) experiment conducted on shrubby vegetation growing on a P-deficient terra-rossa soil on a hilly habitat in the relatively humid eastern Mediterranean region. 


\section{MATERIALS AND METHODS}

\section{Experimental Site}

The experimental site was situated near En Ya'aqov, $15 \mathrm{~km}$ east of the Mediterranean coast, in western Galilee, Israel (lat $33^{\circ} 01^{\prime} \mathrm{N}$, long $35^{\circ} 15^{\prime} \mathrm{E}$; alt $500 \mathrm{~m}$ ). The climate is typical Mediterranean: the average annual precipitation is $806 \mathrm{~mm}$ but with wide inter- and intraseasonal variations $(\mathrm{CV}=32 \%$; Henkin et al. 1998b). During the 17 years of the study (1988/ 1989-2004/2005), the annual rainfall varied between 511 and $1328 \mathrm{~mm}$. The rainy season and, with it, the growing season of the herbaceous vegetation begins in October-November and ends in April-May and is therefore indicated by two calendar years (e.g., 1988/1989). During the summer months, there is little or no rain and no herbaceous growth.

The soil is a montmorillonitic "terra rossa" (Lithic ruptic Xerochrept) with low available phosphorus $\left(\sim 5 \mathrm{mg} \cdot \mathrm{kg}^{-1}\right.$ of bicarbonate-extracted P) overlying Cenomanian-Turonian hard limestone (Dan et al. 1978; Koyumdjiski et al. 1988). Patches of soil up to approximately $0.50 \mathrm{~m}$ deep, some on abandoned terraces, are interspersed between rock outcrops. The terraces have not been cultivated for at least 50 years, but goats grazed the area heavily for several decades, and since 1986 it has been grazed by beef cattle only. In years when hot, dry winds blow during the dry summer months, fire, usually of human origin, is common.

\section{Vegetation}

The vegetation is a typical eastern Mediterranean "batha" shrubland, dominated by S. spinosum (L.) Spach dwarf shrubs (Zohary 1973) interspersed with patches of (mainly annual) herbaceous species. S. spinosum, a species of the Rosaceae family, evidently originated from the semiarid Mediterranean zone and invades abandoned terraces in the humid Mediterranean zone, especially on less fertile soils (Litav et al. 1963). It is often succeeded by C. villosa, a spiny, gorse-like shrub of the nitrogenfixing Fabaceae family. Trees, mainly Kermes oak (Quercus calliprinos Webb.), Pistacia palaestina Boiss., and Crataegus aronia (L.) DC, are sparsely scattered in the landscape. The three dominant herbaceous taxonomical groups are the Poaceae (Crithopsis delileana [Schult. et Schult. F.] Roshev., Aegilops peregrina [Hack.] Maire et Weiller, Bromus spp.); the nitrogenfixing annual Fabaceae species (Trifolium stellatum L., Trifolium pilulare Boiss., Trifolium campestre Schreb., Trifolium purpureum Loisel., Medicago polymorpha L., Medicago rotata Boiss., Scorpiurus muricatus L., Hymenocarpos circinnatus [L.] Savi); and a diverse group of dicotyledonous species, mainly Plantago cretica L., Eryngium creticum Lam., Linum spp., and Hedypnois cretica (L.) Dum.-Courset (Henkin et al. 2006).

\section{Experimental Procedures}

The experiment was initiated during the winter of 1987/1988. Monitoring of shrub cover and biomass production on the patches between the shrubs began in the spring of the 1987/ 1988 season, prior to application of the treatments (Henkin et al. 1998c). In early summer of 1988, a wildfire swept through the entire experimental area. The treatments included a control (P0) with no fertilizer treatment and two P priming treatments. The $\mathrm{P}$ treatments were applied only once, at the beginning of the experiment, and consisted of $45 \mathrm{~kg} \mathrm{P} \cdot \mathrm{ha}^{-1}(\mathrm{P} 1)$ and $90 \mathrm{~kg}$ $\mathrm{P} \cdot \mathrm{ha}^{-1}(\mathrm{P} 2)$. Enriched $\left(25 \% \mathrm{P}_{2} \mathrm{O}_{5}\right)$ superphosphate was applied by hand on the soil surface in the autumn of 1988 after the fire and just before the 1988/1989 rainfall season. In addition, a single selective herbicide (2,4-D, 57\% acid equivalent in a $1.5 \%$ aqueous solution) treatment to control the S. spinosum in the plots was applied at one of two different times: either before the fire, in the spring of 1988 (HE), or 2 years after the fire, in the spring of 1990 (HL). A control plot with no herbicide application was also included (H0). The herbicide treatments were applied only to the P0 and P1 fertilizer treatments, giving a total of seven treatments: HOP0, H0P1, H0P2, HEP0, HEP1, HLP0, and HLP1. All treatments, including the control (HOP0), were on $10 \times 10 \mathrm{~m}$ plots, set out at random in five replicated blocks.

In each year, there was no grazing in the experimental site during the growing season; it was opened to grazing by beef cows at the end of the growing season (May). During the summer (May-September), the cattle were given access to poultry litter as a supplementary source of nitrogen to compensate for the protein deficiency of the dry forage (Silanicove et al. 1987). The feeding troughs were located $1000 \mathrm{~m}$ from the experimental plots. The poultry litter contained approximately $2 \% \mathrm{P}$, most of which would eventually reach the soil in the cattle droppings.

\section{Cover Components}

The relative cover of rock outcrops, canopy cover of shrubs, other woody vegetation, and herbaceous vegetation (recorded as soil patches without shrub cover) was estimated each year in each $10 \times 10 \mathrm{~m}$ plot. The component that lay vertically under each of 100 points arranged as 10 rows of 10 points, spaced at $90 \times 90 \mathrm{~cm}$, was recorded. Soil covered by shrubs (that excluded growth of an herbaceous sward) was recorded as "shrub," whereas rock covered by the overhanging shrub canopy or by herbaceous vegetation was recorded as "rock." The herbaceous vegetation that grew on the soil patches unoccupied by shrubs comprised predominantly annual species and toward the end of the growing season tended to form a closed canopy in all treatments.

\section{Herbaceous Biomass}

The aboveground biomass on the herbaceous sward patches between the shrubs was sampled in April, at the end of each growing season. Five $25 \times 25 \mathrm{~cm}$ quadrats were placed at random in the herbaceous patches in each plot, and all the shoot growth was harvested to ground level. The harvested plant material was oven dried at $75^{\circ} \mathrm{C}$ and weighed. The results are presented as dry matter per herbaceous patch and in the total area of the treatment.

\section{Statistical Analysis}

The responses of S. spinosum and C. villosa cover to the treatments in the early and later phases of the study were analyzed as a repeated-measures analysis of variance model (SAS Institute 2002). Long-term trends of biomass yields in the P0 treatments were analyzed by designating "years" as a continuous variable in a model including herbicide treatment and effective growing days (Henkin et al. 1998b). Cover trend 
of woody vegetation was derived with the trend-line function in Excel format.

\section{RESULTS}

Herbicide Application and Cover of the Vegetation Components The course of change in the cover of the various components of vegetation is illustrated in Figure 1. The herbicide treatment was the source of a major dichotomy (Table 1): without it, the shrubs recovered rapidly after the fire, and their cover exceeded the prefire cover within 5-7 years, whereas in the treatments that included herbicide, shrub cover did not reach prefire levels even in the 17 th year after the fire. Over the whole study, the average cover (least square means) of the shrubs in the herbicide treatments was one-third to one-half of that in the herbicide control treatments (Table 1). P application tended to reduce the shrub cover but not significantly.

\section{P Application and Cover of the Vegetation Component}

Addition of $\mathrm{P}$ generally increased the cover of the herbaceous vegetation at the expense of the woody vegetation (Fig. 1). The higher cover of herbaceous biomass was maintained in all the $\mathrm{P}$ treatments for more than 10 years after the application of the $\mathrm{P}$ fertilizer (Table 2).

In the treatments without herbicide, P reduced the total cover of $S$. spinosum during both the early and the late phases of the study (Fig. 2). Conversely, in the later phase, P2 increased the cover of C. villosa, a leguminous shrub that may have responded to higher $\mathrm{P}$ availability or to the higher initial cover in the P2 treatment. The C. villosa covered some of the $S$. spinosum so that the exposed $S$. spinosum cover hardly changed between the early and later phases of the experiment.

\section{P Application and Productivity of the Herbaceous Vegetation}

P was applied only once, at the beginning of the experiment, yet the biomass in herbaceous patches of the treatments with P was higher than that in the treatments without $\mathrm{P}$ throughout the 17 years of the study (Table 3). By the eighth year (1997), the available $\mathrm{P}$ in the top $3 \mathrm{~cm}$ of soil was not significantly different between treatments (Henkin et al. 1998c). By 2005, the average available $\mathrm{P}$ in the upper soil layer of the three $\mathrm{P}$ treatments without herbicide (H0P0, H0P1, H0P2) ranged between 5.7 and $7.4 \mathrm{mg} \mathrm{P} \cdot \mathrm{kg}^{-1}$ soil, again with no significant differences between them. During the last 7 years, the higher shrub cover and lower herbaceous cover in all treatments depressed the herbaceous biomass yield in the area as a whole (Table 3). In addition, biomass growth on the herbaceous patches at each $\mathrm{P}$ level was higher in the herbicide treatments than in the controls, evidently because of reduced competition from the shrubs, mainly for water.

\section{Rate of Increase in Tree Cover}

There were no significant differences among the treatments in the cover of woody species. Averaged over all the treatments, their cover increased steadily at a rate of $0.0032 \cdot \mathrm{y}^{-1}$ $(r=0.985)$. No young seedlings were observed in the experimental plots; therefore, it can be assumed that the cover of the individual trees was increasing steadily.

\section{DISCUSSION}

\section{Rate of Increase in Shrub Cover}

Without herbicide, the dynamics of the relative cover of the two major shrub species differed. Cover of C. villosa was negligible at the beginning of the experiment (evidently a result of intensive goat grazing over many years before the study; Henkin 2000) and began to increase only 3 years after the fire. On the other hand, S. spinosum increased rapidly immediately after the fire. However, C. villosa grew vigorously and eventually started to overgrow the lower S. spinosum shrubs. By the sixth year, the total cover of $S$. spinosum (including that overgrown by C. villosa) began to stabilize (Fig. 2): between 1999 and 2005, the trend of total S. spinosum cover versus year (as a continuous variable) was significantly negative $\left(-1.38 \cdot y^{-1}, P<0.004\right)$, whereas the trend of C. villosa versus year was positive $\left(1.93 \cdot \mathrm{y}^{-1}, P<0.0001\right)$. After 2003, the cover of C. villosa also began to stabilize (Fig. 2).

In the treatments where herbicide application had killed most of the shrubs, both species encroached slowly, and their covers were positively correlated $(r=0.74-0.94)$ during the last 7 years of the experiment. Evidently, competition with the herbaceous vegetation, mainly for water during the dry summer, inhibited recruitment of shrub seedlings of both species (Litav et al. 1963; Henkin et al. 1998a). Indeed, such recruitment was rare in the present study. Consequently, the mechanism underlying the shrub encroachment was mainly the increase in cover of the individual surviving shrubs. The density of regenerating buds would, therefore, set a medium-term limit to shrub cover expansion as long as there was a limit to the cover and size of individual shrubs under the study conditions. The importance of the initial composition of the vegetation in determining vegetation dynamics is well established (Egler 1954) and could be the reason for the differing peak levels of shrub cover attained in the various treatments (Fig. 1). Shrub cover expansion to such limits can be well described as a logistic function, and the asymptotic limit for the function can be derived from the peak values.

Initially, there would be very little interaction between the shrubs, so that the initial rate of increase in cover could reflect each specific expansion rate, $a$, as a characteristic of each of the two shrub species. In an earlier phase of this study, logistic functions were fitted to a smaller data set (Henkin et al. 1999). The average $( \pm \mathrm{SE})$ values for $a$ were $0.74 \pm 0.07$ and $0.77 \pm 0.04$ for $S$. spinosum and C. villosa, respectively. The logistic function for numerical integration,

$$
y_{t}=y_{(t-1)}+a y_{(t-1)}\left(1-\frac{y_{(t-1)}}{y_{x}}\right)
$$

was fitted to the larger data set available in this study by setting $y_{0}$ and $y_{x}$ equal to the observed initial $\left(y_{0}\right)$ and maximum $\left(y_{x}\right)$ values and optimizing the values of $a$. The calculated and observed results are presented in Figure 3.

The initial cover of the shrubs after the fire and especially after the herbicide treatments was small. Cover less than $1 \%$ in any replicated plot was not recorded, and in many cases $1 \%$ cover was recorded in only one of the five replications of a treatment. The presence of C. villosa in a treatment replication was recorded for the first time only some years 

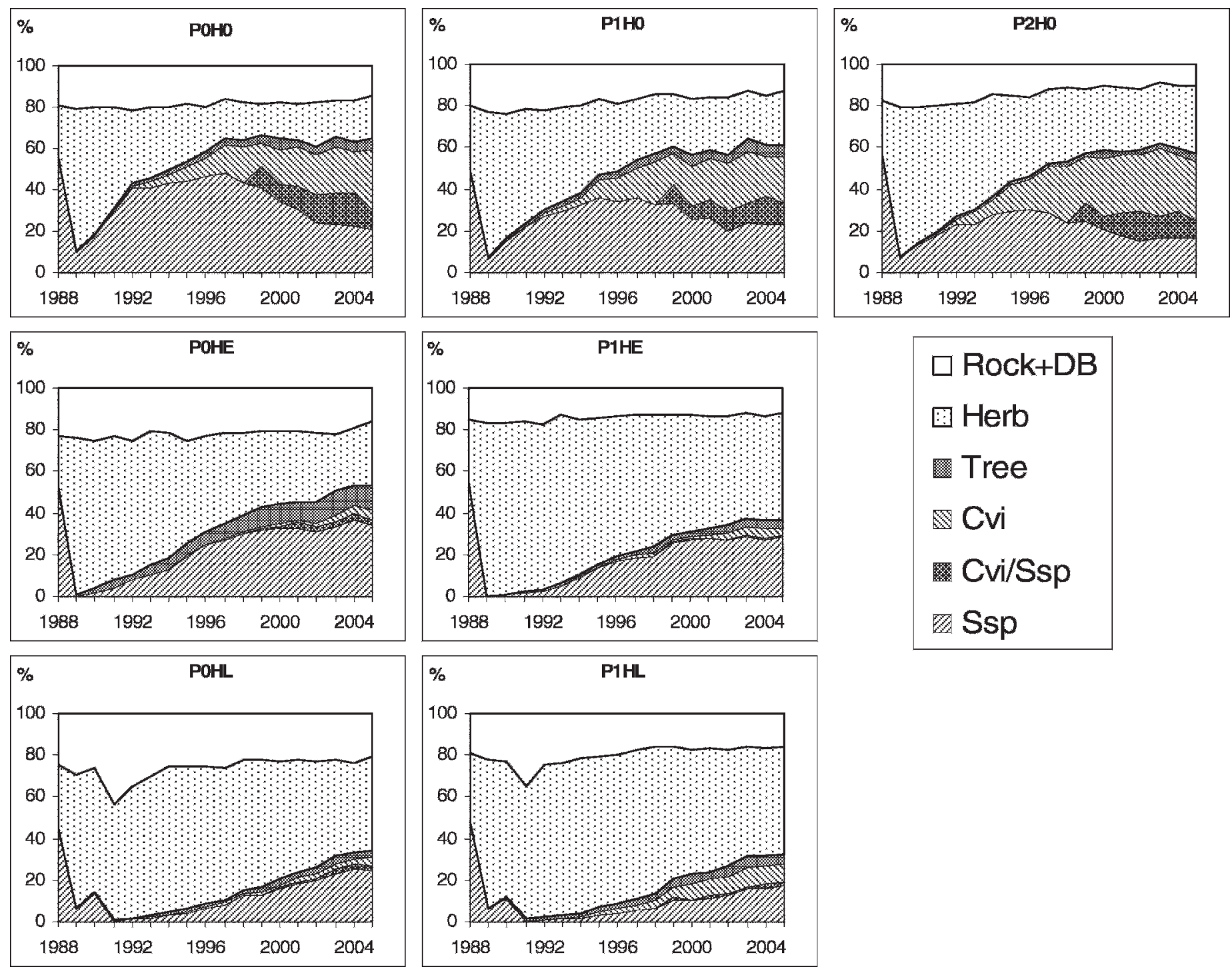

Figure 1. Effects of treatments on the course of cover change of the vegetation components at En Ya'aqov, Israel, 1988-2005 (DB indicates dead brush; Herb, herbaceous vegetation; Cvi, Calicotome villosa; and Ssp, Sarcopoterium spinosum).

after the fire or herbicide application, especially in the case of the HL treatments. The initial values $\left(y_{0}\right)$ for the logistic function for C. villosa were, therefore, derived from different years. The asymptotic values of the function $\left(y_{x}\right)$ were derived from the peak values in the various treatments. Therefore, the fitted functions in different treatments cover different periods.

The $y_{0}$ values differed widely among the treatments. The high $y_{0}$ values of $S$. spinosum in the $\mathrm{H} 0$ treatments can be ascribed to the regenerating shrubs that survived the fire. After

Table 1. Average cover (least square means) of shrubs (Sarcopoterium spinosum + Calicotome villosa) throughout the experiment (19882004). ${ }^{1}$

\begin{tabular}{lccc}
\hline & P0 & P1 & P2 \\
\hline HO & $49.1 \mathrm{a}$ & $41.7 \mathrm{a}$ & $41.9 \mathrm{a}$ \\
HE & $24.4 \mathrm{~b}$ & $19.1 \mathrm{~b}$ & \\
HL & $14.1 \mathrm{~b}$ & $13.5 \mathrm{~b}$ & \\
\hline
\end{tabular}

$\overline{{ }^{1} P<0.0001}$, SE $($ diff. $)=3.99$. Letters indicate significant differences $(P<0.05)$ between treatments by Tukey's HSD test. the herbicide applications (treatments HE, HL), initial cover was diminished by an order of magnitude. In these treatments, the single $P$ application seemed to hasten the appearance of $C$. villosa and to delay the appearance of $S$. spinosum. The variation among the $y_{0}$ values in the herbicide treatments (Table 4) could have been the source of spurious differences in the fitted specific expansion rates $(a)$ in these treatments.

Table 2. The response of cover (\%) of the herbaceous vegetation during the later phase of the experiment (mean values for the period 1999-2005) to the single application of phosphorus and herbicide during 1988-1990. ${ }^{1}$

\begin{tabular}{lccc}
\hline Treatment & P0 & P1 & P2 \\
\hline HO & $19 \mathrm{~d}$ & $26 \mathrm{~cd}$ & $30 \mathrm{bcd}$ \\
$\mathrm{HE}$ & $32 \mathrm{bc}$ & $53 \mathrm{a}$ & \\
$\mathrm{HL}$ & $51 \mathrm{ab}$ & $56 \mathrm{a}$ & \\
\hline
\end{tabular}

$\overline{{ }^{1} P=0.0020, \text { SE }(\text { diff. })=5.21 \text {. Letters indicate significant differences }(P<0.05) \text { between }}$ treatments by Tukey's HSD test. 

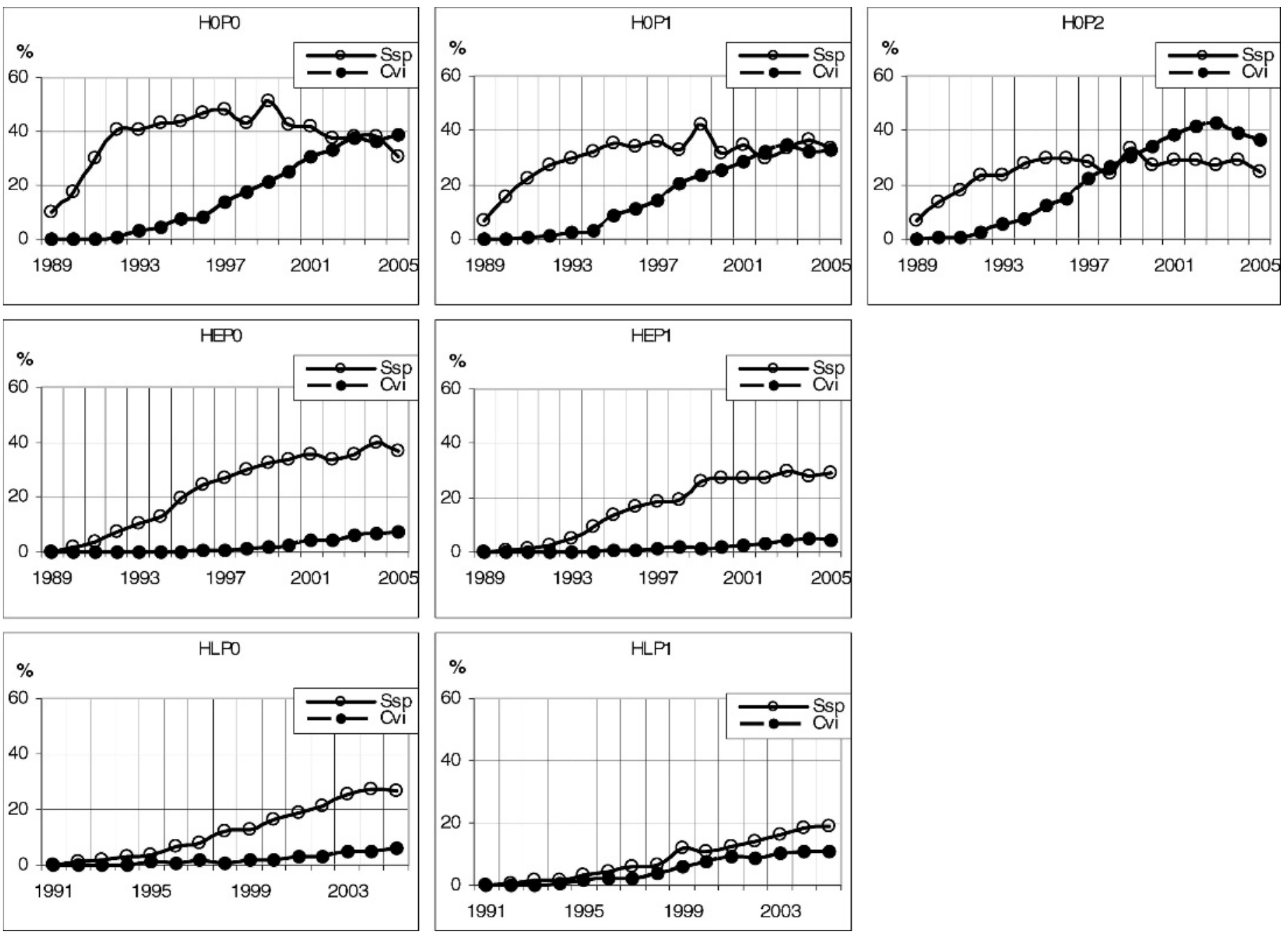

Figure 2. Treatment effects on the cover of Calicotome villosa (Cvi) and Sarcopoterium spinosum (Ssp; including $S$. spinosum under C. villosa). Gradient of year-effect plot after 1999 (all treatments): $S$. spinosum: $-0.027(P=0.94) ; C$. villosa: $+1.35(P<0.0001)$. Gradient of year-effect plot after 1999 (H0 treatments only): $S$. spinosum: $-0.46(P=0.41)$; C. villosa: $+1.88(P<0.0001)$.

Table 3. Peak season dry biomass during the first 8 years (1989-1996) and last 9 years (1997-2005) of the study on herbaceous patches and on the total area of the treatment $\left(\mathrm{g} \cdot \mathrm{m}^{-2}\right.$, mean $\left.\pm \mathrm{SE}\right) .^{1}$

\begin{tabular}{|c|c|c|c|c|}
\hline \multicolumn{5}{|c|}{ Herbaceous patches } \\
\hline \multirow[b]{2}{*}{ Treatment } & \multicolumn{2}{|c|}{ First years } & \multicolumn{2}{|c|}{ Last years } \\
\hline & P0 & P1 & P0 & P1 \\
\hline $\mathrm{HO}$ & $100 \pm 10 \mathrm{~h}$ & $287 \pm 32 b c$ & $150 \pm 17 \mathrm{gh}$ & $276 \pm 20 \mathrm{bcd}$ \\
\hline HE & $191 \pm 17 \mathrm{fg}$ & $323 \pm 36 a b$ & $221 \pm 18$ def & $304 \pm 27 a b c$ \\
\hline $\mathrm{HL}$ & $203 \pm 23$ efg & $367 \pm 37 a$ & $258 \pm 24$ cde & $336 \pm 28 a b$ \\
\hline \multicolumn{5}{|c|}{ Total area (community) } \\
\hline & \multicolumn{2}{|c|}{ First years } & \multicolumn{2}{|c|}{ Last years } \\
\hline Treatment & PO & P1 & P0 & P1 \\
\hline $\mathrm{HO}$ & $44 \pm 10 \mathrm{gh}$ & $140 \pm 22$ de & $29 \pm 5 \mathrm{~h}$ & $73 \pm 5 \mathrm{fgh}$ \\
\hline HE & $118 \pm 9$ ef & $252 \pm 27 \mathrm{ab}$ & $84 \pm 8 \mathrm{fg}$ & $180 \pm 17 \mathrm{~cd}$ \\
\hline $\mathrm{HL}$ & $135 \pm 16$ de & $262 \pm 25 a$ & $145 \pm 17 \mathrm{de}$ & $210 \pm 22 b c$ \\
\hline
\end{tabular}

${ }^{1}$ Letters indicate significant differences $(P<0.05)$ between treatments by Tukey's HSD test. 

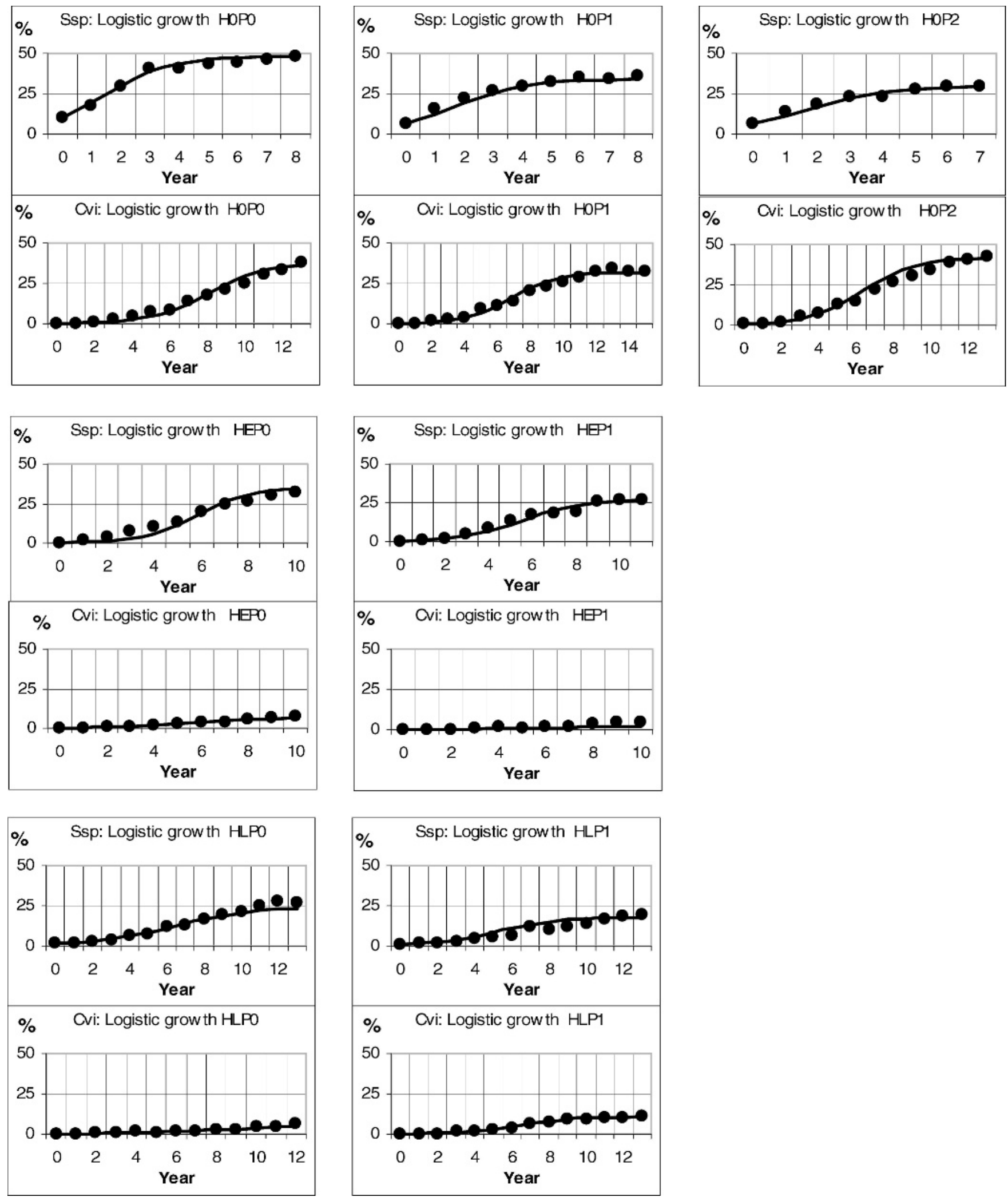

Figure 3. Logistic fit (-) on observed percentage cover (•) of Sarcopoterium spinosum (Ssp) and Calicotome villosa (Cvi).

As a rule, fertilizer application that increased the herbaceous biomass decreased the specific expansion rate $(a)$ of $S$. spinosum. There was no clear effect of fertilizer application on the $a$ values of C. villosa. This could be the result of the compensating effect of $\mathrm{P}$ on C. villosa growth. The global average specific expansion rates of S. spinosum and C. villosa was $0.74 \cdot y^{-1}$ and $0.56 \cdot y^{-1}$, respectively. This indicates that their encroachment was rapid: initially their cover doubled in 
Table 4. Values used in the logistic function to describe the expansion of cover of Sarcopoterium spinosum and Calicotome villosa in the treatments of the experiment ( $a$ indicates specific expansion rate; $y_{0}$, initial value; $y_{x}$, observed peak cover).

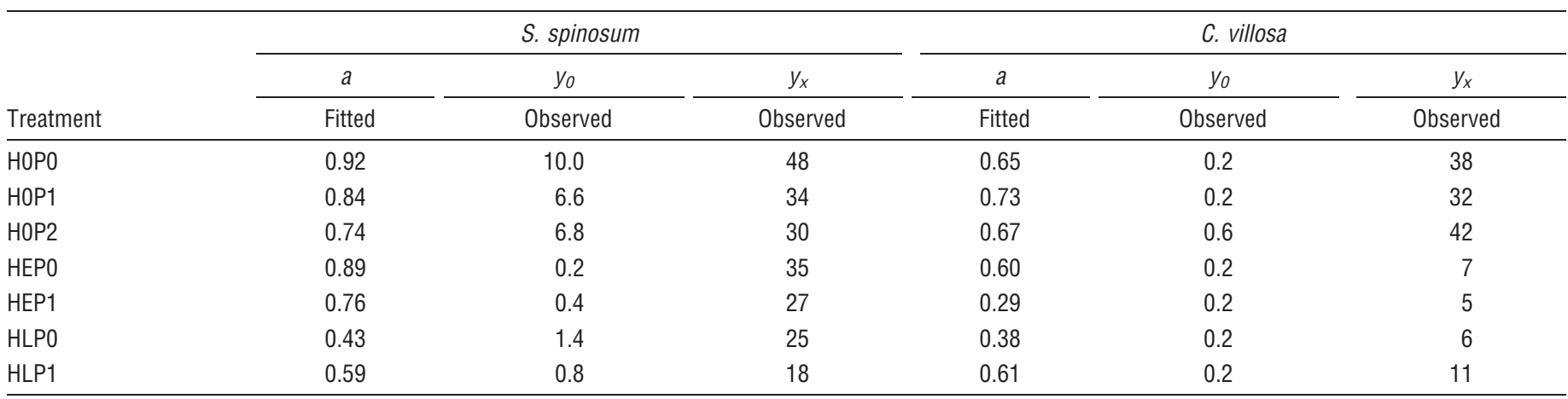

2-4 years. For comparison, the (linear) encroachment rate of the trees in the experimental area under current grazing conditions was only $0.003 \cdot \mathrm{y}^{-1}$. Since the shrubs exhibit such relatively high specific growth rates, keeping the initial values low is the key to long-term maintenance of herbaceous swards that are relatively free of shrub encroachment.

\section{Residual Effect of a Single Application of $\mathbf{P}$}

The enhancement of herbaceous biomass production throughout the study period, after a single application of $\mathrm{P}$, invites comment, especially in view of the fact that by the sixth year, there was no significant difference in bicarbonate extractable soil $\mathrm{P}$ among treatments. Recycling of $\mathrm{P}$ in the seeds and litter of the annual herbaceous vegetation was one source of available P. In addition, the cattle that grazed the area during the dry summer had access to poultry litter that contained about $2 \% \mathrm{P}$, most of which would have been excreted in the feces. Accumulation of excreted $\mathrm{P}$ could be the reason for the higher biomass production during the later phase of the study in the P0 treatments and the maintenance of higher productivity in the $P$ treatments (Table 3 ). The year effect is significant $(P=0.0014)$, when the effective growing days (Henkin et al. 1998b) are taken into account. In addition, the increase in legume cover could well have increased the availability of nitrogen in the system. Whatever the reason, the priming effect of the original $\mathrm{P}$ application not only maintained the productivity of the herbaceous vegetation but also was expressed in the lower rates of shrub encroachment. The fact that the higher biomass production and P uptake were not accompanied by higher bicarbonate extractable $\mathrm{P}$ in the soil probably indicates that the organic $\mathrm{P}$ is a separate $\mathrm{P}$ store (Katznelson 1977).

\section{Dominant States and Transitions}

Constant, unchanging ecological conditions are rare in the Mediterranean region, so that stability must be defined in terms of specific time scales. For many management objectives, 10-50 years is a relevant time horizon. Within such time scales, some vegetation states can be regarded as stable (or quasi-stable) states. There were many intermediate vegetation states on the study site (Fig. 1), but three states were dominated by a major vegetation component: herbaceous swards, S. spinosum shrublands, and C. villosa thickets. These states were sharply distinguished on the scale of $\sim 1 \mathrm{~m}^{2}$ and often on considerably larger scales as well. Under appropriate ecological conditions, these three states can be relatively stable on a time scale of two to three decades. There are six potential transitions between the three states (Fig. 4). The tree component could become a dominant component of the vegetation, but at the prevailing rate of cover increase of $0.32 \% \cdot y^{-1}$, it would take more than 50 years for the tree cover to exceed $20 \%$ (unless at some stage its expansion were to change from linear to exponential). On shorter time scales, changes in tree cover can be ignored. With the aid of the data obtained from the present study, together with supplementary data from associated studies, it is possible to define the conditions necessary for transitions from one state to another, either as a successional process or as a "degradation" process in response to management interventions (Westoby et al. 1989; Stringham et al. 2003). The initial conditions and the rates of cover increase can be used with some confidence to estimate the time required for transitions between the three states. Appropriate timing of interventions can then maintain a fluctuating dynamic equilibrium between the successional processes and management-directed disturbances. The resultant vegetation states then become relatively stable as long as the management context is maintained. Indeed, most landscapes in populated regions are dynamic equilibria between successional processes and human activity (Naveh and Lieberman 1994).

\section{Successional and Management Factors}

Intensive use of resources, including terracing, cultivation, fuel and food collection, heavy grazing, and occasional fires, has opened up the habitats in the study region to the establishment of many herbaceous species (Baker and Stebbins 1965; Henkin et al. 2006). With reduction in the intensity of resource use (especially cultivation of soil patches and terraces), the pioneer annual herbaceous vegetation initially dominates the landscape. On typical Mediterranean karstic habitats, shrubs and, later, trees become established by rooting into the deep fissures in the hard limestone substrate (Shachori et al. 1967). Once established, they can satisfy their soil moisture requirement in summer with water from the deeper layers of the rock-soil complex, well beyond the rooting depth of the herbaceous vegetation (Rosenzweig 1972). The first to dominate is $S$. spinosum, possibly because of rapid root elongation of the seedling (Litav and Orshan 1971). C. villosa can germinate 


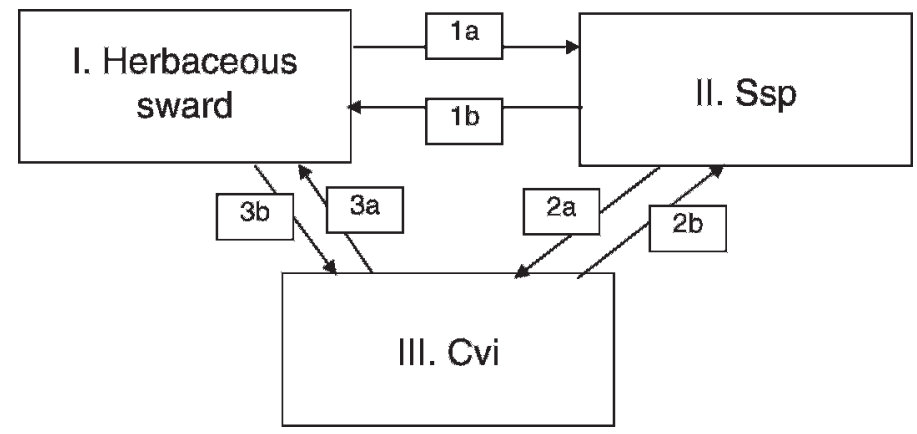

Figure 4. States and transitions relevant to a Mediterranean shrubland growing on P-deficient terra rossa. Ssp indicates Sarcopoterium spinosum; Cvi, Calicotome villosa.

beneath the $S$. spinosum cover (personal observation) and eventually overgrows the $S$. spinosum to become the dominant element in the landscape (e.g., treatments $\mathrm{H} 0$ in Fig. 1). Evidently, C. villosa can dominate for decades, even in the face of sporadic fires, until it is overshadowed by the developing tree cover, which is commonly Quercus calliprinos and associated species (Zohary 1973).

The main management interventions include grazing, fuel and woodcutting for fuel, shrub control with herbicides or by mechanical means, amelioration of plant mineral deficits in the soil, and fire. The effects of grazing depend on the dietary preferences of the various grazing animal species, the season of grazing, and the grazing pressure. Goats graze S. spinosum mainly in early winter and select C. villosa preferentially during winter and early spring. Under heavy grazing by goats, the cover of both S. spinosum and C. villosa is reduced, but whereas C. villosa is especially sensitive to such grazing and can be browsed almost to extinction, S. spinosum is more resistant. Cattle graze both $S$. spinosum and C. villosa reluctantly and have virtually no effect on the cover of either of them (Gutman et al. 2000). Fuel gathering and woodcutting in the past were important factors in determining the appearance of the landscape, but today these activities have virtually ceased. Shrub control with herbicides is a possible technological intervention, and the rate of recovery of the affected shrubs depends mainly on the shrub control efficiency, which, in turn, determines the cover of the surviving shrubs and the initial values for the recovery process. Where the soil mineral resources are low, addition of the deficient element can trigger a feedback process whereby increased production is maintained for some time by recycling of the deficient element. Exogenous sources, as in the case of $\mathrm{P}$ deposition by grazing animals that have access to P-rich supplementary feed, can also increase productivity of the herbaceous vegetation (Treatment P0 in Table 3). Added P also increased the cover of annual legumes (Henkin et al. 2006) and, consequently, the amount of nitrogen entering the system. Leguminous shrubs such as C. villosa can also benefit from added $\mathrm{P}$ and increase their cover more rapidly (Fig. 1). Fire has mainly transient effects on the shrub vegetation, which recovers to prefire cover levels within 5 years. The complementary effect on the increase of the herbaceous vegetation cover is similarly transient.

In the light of this background, the conditions necessary for the six transitions can be defined (Table 5).
Requirements for transitions between the states:

- 1a. Herb $\rightarrow$ S. spinosum:

On relatively poor soils overlying karstic substrate, this is the spontaneous successional transition in this region when $S$. spinosum mother plants are present. Dwarf shrubs dominate nutrient-poor habitats because of greater ability to absorb and conserve nutrients like phosphorus (Rabinovich-Vin 1979). Intensive cattle grazing, especially in the growing season of herbaceous plants in winter and spring, may hasten this transition, whereas very heavy grazing by goats that graze the $S$. spinosum tends to retard it.

- 1b. S. spinosum $\rightarrow$ Herb:

Fire reduces $S$. spinosum cover and causes the death of some shrubs and so promotes the appearance of a transient herbaceous cover. Within 5 years, $S$. spinosum cover returns to the prefire level, but efficient shrub control (chemical or mechanical) can delay this recovery for more than 10 years. It is likely but has not yet been demonstrated that $S$. spinosum could be reduced to a negligible level by two or three repeated applications of herbicide for shrub control. Reestablishment of $S$. spinosum seedlings is sensitive to competition from herbaceous vegetation; therefore, vigorous herbaceous growth following addition of $\mathrm{P}$ to P-deficient soils, together with light or deferred grazing during the growing season, can delay the recovery of $S$. spinosum even longer. Deposition of $\mathrm{P}$ in summer by grazing cattle that are supplemented with P-rich poultry litter is a source of exogenous $\mathrm{P}$ (and other nutrients) that could eventually maintain productive herbaceous swards for decades (Weeda 1967).

- 2a. S. spinosum $\rightarrow$ C. villosa:

In the study region, this is the successional trend especially if goat grazing is absent or light. C. villosa germinates and establishes preferentially among $S$. spinosum shrubs and, being taller, eventually overshadows them and becomes dominant despite a lower initial growth rate. When $\mathrm{P}$ is added to P-deficient soils, C. villosa cover tends to increase more rapidly unless it has been severely suppressed by effective shrub control, as in the case of treatment HEP1 (Fig. 1).

- 2b. C. villosa $\rightarrow$ S. spinosum:

C. villosa is preferentially grazed by goats (Weitz 1964; Kababya et al. 1998), and intensive grazing by goats over many years (decades) can reduce C. villosa cover almost to extinction (Henkin 2000). S. spinosum cover is also reduced by intensive goat grazing, but $S$. spinosum shrubs persist as a dominant element of the vegetation, possibly because they are grazed for shorter periods than C. villosa and because of their ability to regenerate by clonal propagation (Seligman and Henkin 2000). 
Table 5. Management interventions that are necessary for specific transitions to take effect. ${ }^{1}$

\begin{tabular}{|c|c|c|c|c|c|c|c|}
\hline \multirow[b]{3}{*}{ Transition } & \multicolumn{7}{|c|}{ Management } \\
\hline & \multicolumn{3}{|c|}{ Grazing } & \multirow[b]{2}{*}{ Herbicide } & \multirow[b]{2}{*}{$\mathrm{P}$ addition } & \multirow[b]{2}{*}{ Fire } & \multirow{2}{*}{$\begin{array}{c}\text { Mechanica } \\
\text { clearing }\end{array}$} \\
\hline & Goats, yearlong & Cattle, green season & Cattle, dry season ${ }^{2}$ & & & & \\
\hline 1a. Herb $\rightarrow$ Ssp: & $\leq$ Moderate? & Yes & No & No & No & No & No \\
\hline 1b. Ssp $\rightarrow$ Herb: & Intensive? & No & No & Yes & Yes & Yes & Yes \\
\hline 2a. Ssp $\rightarrow$ Cvi: & No & Yes & Yes & No & Yes & Maybe & No \\
\hline 2b. Cvi $\rightarrow$ Ssp: & Intensive & No & No & No & No & Maybe & No \\
\hline 3a. Cvi $\rightarrow$ Herb: & Intensive & No & No & Yes & No & Yes & Yes \\
\hline 3a. Herb $\rightarrow$ Cvi: & No? & Yes? $?^{3}$ & No? & No & Maybe & No & No \\
\hline
\end{tabular}

${ }^{1}$ Ssp indicates Sarcopoterium spinosum; Cvi, Calicotome villosa; Herb, herbaceous vegetation; and ?, deduced without hard evidence.

${ }^{2}$ With poultry litter as a component of the supplementary feed.

${ }^{3}$ When area was previously dominated by $C$. villosa.

- 3a. C. villosa $\rightarrow$ Herb:

Fire reduces C. villosa cover and promotes the appearance of a transient herbaceous cover for 3-6 years (Gutman et al. 2000). Intensive goat grazing can also promote this transition. C. villosa is sensitive to 2,4-D, which, when applied efficiently, can keep its cover very low. Addition of $\mathrm{P}$ to promote herbaceous growth can sometimes also promote C. villosa growth (Fig. 1), but there is little if any evidence in our present study that $\mathrm{P}$ affected the direct transitions $\mathrm{C}$. villosa $\rightarrow$ Herb and Herb $\rightarrow$ C. villosa (as distinct from transitions via $S$. spinosum). Therefore, statements on these transitions are still speculative.

- 3b. Herb $\rightarrow$ C. villosa:

This transition can occur only in an area previously dominated by C. villosa and cleared of it by fire or mechanically, particularly in the absence of $S$. spinosum. In such a case, the transient sward of herbaceous vegetation may be recolonized by $C$. villosa, usually within 3-6 years (Gutman et al. 2000).

\section{Objectives of Landscape Use}

Each of the vegetation states has characteristics that favor specific objectives. If the dominant landscape use is cattle grazing, herbaceous swards are preferred. C. villosa has beautiful yellow flowers with a rich, sweet aroma; they provide nectar and pollen for bees and also make a very attractive show in spring. $S$. spinosum and, particularly, C. villosa provide forage for goats for some months of the year. They also provide refuges for perennial grasses and other species sensitive to grazing (personal observation). Recreational activities are best served by a moderately open, herbaceous landscape interspersed with patches of shrubs (Henkin et al. 2004). The explicit definition of the transitions and their durations can, therefore, be a useful landscape planning and management tool.

\section{Dynamic Equilibria as a Management Goal}

Any management goal that involves divergence from the successional trends in the region requires intervention, and each intervention has differing relaxation times in the different vegetation states. The effects of various interventions and disturbances (including fire, fertilization, herbicide, and grazing by different classes of animals) under different environmental conditions has been discussed by Heady and Child (1994). The scale of the intervention and its intensity will depend on both economic and ecological considerations. With intervention, any of the defined states can be maintained in a condition of dynamic equilibrium between each other. However, maintaining such a condition requires awareness of the current state of the vegetation in order to determine the type and timing of the appropriate intervention and the facilities necessary to implement it.

For instance, if the objective in the study region is to maintain an herbaceous sward, shrub encroachment can be delayed more economically if shrub control is applied when shrub cover is low rather than if it is postponed until shrubs dominate the vegetation. In addition, $\mathrm{P}$ fertilizer application can both increase herbaceous biomass production and suppress the establishment of shrub seedlings. Maintenance of a productive herbaceous sward may require periodic replenishment of $\mathrm{P}$. The higher biomass production can then trigger a positive feedback by increasing the time the animals spend on the pasture and increase the deposition of dung. If the biomass is grazed during the dry summer when the animals have free access to supplementary feed rich in phosphorus (like poultry litter), then the $\mathrm{P}$ excreted by the grazing animals could well maintain herbaceous productivity for a longer period.

On the other hand, if the objective were to maintain a mixed stand of shrubs and herbaceous patches, herbicide and fertilizer interventions could be limited to designated herbaceous patches. Shrub encroachment into vigorous herbaceous swards is very slow, even in the presence of adequate seed resources (Litav et al. 1963), and can be easily controlled during the early stage of shrub establishment. Alternatively, goat grazing could be introduced to keep the shrubs from dominating the vegetation. The costs of the various alternatives as well as their feasibility will depend on the socioeconomic context.

Another objective could be maintenance of an "ecological landscape" with minimum cost and minimum economic utilization in which the successional processes and natural disturbances such as fire are allowed to take their course. Under the prevailing habitat conditions, this would lead to the area being dominated by thorny shrub thickets for many decades. Eventually, in 50-100 years, with infrequent occurrence of patchy fires, the tree component will most probably dominate the vegetation. 


\section{ACKNOWLEDGMENTS}

Research in Israel was funded by the Northern Israel R\&D Unit, the Jewish National Fund, the Soil Conservation Division of the Israel Ministry of Agriculture and Rural Development, and the International Arid Lands Consortium (IALC). Soil and plant analyses were performed at the chemical laboratory of MIGAL, the Galilee Technological Centre, Qiryat Shemona. Special thanks are due to Mrs Havah Aharon for aid in preparation of the data for analysis.

\section{LITERATURE CITED}

Allen-Diaz, B., and J. W. Bartolome. 1998. Sagebrush-grass vegetation dynamics: comparing classical and state-transition models. Ecological Applications 8:795-804.

Baker, H. G., and G. L. Stebbins. 1965. The genetics of colonizing species. New York, NY: Academic Press. 588 p.

Bestelmeyer, B. T., J. R. Brown, K. M. Havstad, R. Alexander, G. Chavez, and J. E. HerRick. 2003. Development and use of state-and-transition models for rangeland. Journal of Range Management 56:114-126.

Dan, J., D. Yaalon, H. KoyumdiskY, and Z. Raz. 1978. The soils of Israel. Bet Dagan, Israel: Division of Scientific Publications, AR0, the Volcani Center. Pamphlet 159. $30 \mathrm{p}$.

EgleR, F. E. 1954. Vegetation science concepts: I. Initial floristic composition, a factor in old field vegetation development. Vegetatio 4:412-417.

Feinbrun-Dothan, N., and A. Danin. 1991. Analytical flora of Eretz-Israel. Jerusalem: CANA Publishing House Ltd. $1040 \mathrm{p}$.

Gutman, M., Z. Henkin, Z. Holzer, I. Noy-Meir, and N. G. Seligman. 2000. A case study of beef-cattle grazing in a Mediterranean-type woodland. Agroforestry Systems 48:119-140.

Heady, H. F., and R. D. Child. 1994. Rangeland ecology and management. Boulder, C0: Westview Press. 519 p.

HenKIN, Z. 2000. Reduction of goat grazing as a factor in the encroachment of Calicotome villosa bushes in the natural brush land of the Galilee. Ecology and Environment 6:104-108. (in Hebrew)

Henkin, Z., L. Hadar, And I. Noy-Meir. 2004. Effect of cattle and goat grazing on landscape features and human visual qualities in Northern Israel. In: M. Arianoutsou and V. Papanastasis [EDS.]. Proceedings of the 10th MEDECOS Conference; 24 April-1 May; Rhodes, Greece. Rotterdam: Millpress.

Henkin, Z., N. G. Seligman, U. Kafkafi, and D. Prinz. 1998a. End-of-season water depletion in relation to growth of herbaceous vegetation in a sub-humid Mediterranean dwarf-shrub community on two contrasting soils. Plant and Soil 202:317-326.

Henkin, Z., N. G. Seligman, I. Noy-Meir, and U. Kafkafi. 1998b. "Effective growing days": a simple predictive model of the response of herbaceous plant growth in a Mediterranean ecosystem to variation in rainfall and phosphorus availability. Journal of Ecology 86:137-148.

Henkin, Z., N. G. Seligman, I. Noy-Meir, and U. Kafkafi. 1999. Secondary succession after fire in a Mediterranean dwarf-shrub community. Journal of Vegetation Science 10:503-514.

Henkin, Z., N. G. Seligman, I. Noy-Meir, U. Kafkafi, and M. Gutman. $1998 \mathrm{c}$. Rehabilitation of Mediterranean dwarf-shrub rangeland with herbicides, fertilizer and fire. Journal of Range Management 51:193-199.

Henkin, Z., M. Sternberg, N. G. Seligman, and I. Noy-Meir. 2006. Species richness in relation to phosphorus and competition in a Mediterranean dwarf-shrub community. Agriculture, Ecosystems and Environment 113:277-283.

Kababya, D., A. Perevolotsky, I. Bruckental, and S. Landau. 1998. Selection of diets by dual-purpose Mamber goats in Mediterranean woodland. Journal of Agricultural Science (Cambridge) 131:221-228.

Katznelson, J. 1977. Phosporus in the soil-plant-animal ecosystem. Oecologia Plantarum 26:325-334.

Koyumdiski, H., J. Dan, S. Soriano, and S. Nissim. 1988. Selected profiles from Israeli soils. Bet Dagan, Israel: AR0, the Volcani Center. 244 p. (in Hebrew)
Litav, M., G. KuperniK, and G. Orshan. 1963. The role of competition as a factor in determining the distribution of dwarf shrub communities in the Mediterranean territory of Israel. Journal of Ecology 51:467-480.

Litav, M., and G. Orshan. 1971. Biological flora of Israel. 1. Sarcopoterium spinosum (L.) sp. Israel Journal of Botany 20:48-64.

NAVEH, Z. 1974. The role of fire in the Mediterranean region. In: T. T. Kozlowski and C. E. Ahlgren [eds.]. Fire in ecosystems. New York, NY: Academic Press. p. 401-434.

NAVEH, Z. 1975. The evolutionary significance of fire in the Mediterranean region. Vegetatio 29:199-208.

Naven, Z., AND J. Dan. 1973. The human degradation of Mediterranean landscapes in Israel. In: F. Di Castri and H. A. Mooney [EDS.]. Mediterranean-type ecosystems: Origin and structure. Berlin: Springer-Verlag. p. 373-390.

Naveh, Z., and A. S. LieBerman. 1994. Landscape ecology-Theory and applications. 2nd ed. New York, NY: Springer-Verlag. $360 \mathrm{p}$.

Ofer, Y., and N. Seligman. 1969. Fertilization of annual range in Northern Israel. Journal of Range Management 22:337-341.

Perevolotsky, A., and N. G. Seligman. 1998. Grazing in Mediterranean ecosystems: inversion of a paradigm. BioScience 48:1007-1017.

PretTY, J. 2002. Agri-culture: Reconnecting people, land and nature. London: EARTHSCAN Publications Limited. $261 \mathrm{p}$.

Rabinovich-VIN, A. 1979. Influence of parent rock on soil properties and composition of vegetation in the Galilee [PhD thesis]. Israel: The Hebrew University of Jerusalem. 212 p. (in Hebrew with English summary)

Rabinovich-VIN, A., AND G. ORShan. 1974. Ecological studies on the vegetation of the upper Galilee, Israel. 2. Factors determining the absence of bata and garigue components on middle eocenian strata. Israel Journal of Botany 23:111-119.

Reisman-Berman, 0. 2004. Mechanisms controlling spatio-temporal dynamics of shrubland patchiness: Case study of Sarcopoterium spinosum (L) Spach [PhD thesis]. Beer-Sheva, Israel: Ben-Gurion University of the Negev. 236 p.

Rivas Martinez, S. 1987. Memoria del Mapa de Series de Vegetation de España. In: ICONA, Publicaciones del Ministerio de Agricultura, Pesca y Alimentacion. Madrid: Ministerio de Agricultura. $268 \mathrm{p}$.

RosenzWEIG, D. 1972. Study of the difference in effects of forest and other vegetative covers on water yield. Chapter 5 in Research Report 33. Tel Aviv: Soil Conservation and Drainage Department, Ministry of Agriculture. $17 \mathrm{p}$.

Rundel, R. W., G. Montenegro, and F. M. Jaksic. 1998. Landscape disturbance and biodiversity in Mediterranean-type ecosystems. Volume 136, Ecological Studies. New York, NY: Springer. 447 p.

SAS InstiTUTE. 2002. JMP statistics and graphics guide. Version 5. Cary, NC: SAS Institute. $1727 \mathrm{p}$.

Seligman, N. G., and Z. Henkin. 2000. Regeneration of a dominant Mediterranean dwarf-shrub after fire. Journal of Vegetation Science 11:893-902.

Shachori, A., D. Rosenzweig, and A. Poljakoff-Mayber. 1967. The effect of Mediterranean vegetation on the moisture regime. In: W. E. Sopper and W. A. Hull [EDS.]. International symposium on forest hydrology. Oxford: Pergamon Press. p. 291-310.

Silanicove, N., Z. Holzer, D. Cohen, R. W. Benjamin, M. Gutman, and A. Melzer. 1987. Interrelationship between metabolism of tritiated water, sodium and dry matter in beef cows fed poultry litter and wheat straw in free choice. Comparative Biochemistry and Physiology 88:113-118.

Stringham, T. K., W. C. Krueger, and P. L. Shaver. 2003. State and transition modeling: an ecological process approach. Journal of Range Management 56:106-113.

WeEDA, W. C. 1967. Effect of cattle dung patches on pasture growth, botanical composition, and pasture utilization. New Zealand Journal of Agricultural Research 10:150-159.

WeITZ, M. 1964. Goat grazing in Mediterranean woodland: Observations conducted at Fassuta in the Galilee. Tel Aviv: Soil Conservation Division, Ministry of Agriculture. 74 p.

Westoby, M., B. Walker, and I. Noy-MeiR. 1989. Opportunistic management for rangelands not at equilibrium. Journal of Range Management 42:266-274.

Zohary, M. 1973. Geobotanical foundations of the Middle East. Stuttgart: Gustav Fischer Verlag; Amsterdam: Swets and Zeitlinger. $739 \mathrm{p}$. 